\title{
Teknoloji ile Zenginleştirilmiş Öğrenmeye Yönelik Öğretim Elemanı Geliştirme Altyapısı*
}

\author{
Faculty Development Infrastructure Intended for \\ Technology Enhanced Learning
}

\author{
Yrd. Doç. Dr. Alev Elçi
}

\section{Öz}

Eğitimin ulusal sınırlardan küresel bir boyuta taşındığı ve bilgi toplumu olma yolunda politikalarm ön plana çıtığı günümüzde, Türkiye'de yükseköğretim kurumlarl ve öğrenci sayısındaki büyümenin salt niceliksel değil niteliksel olarak da amaçlanması gerekmektedir. Bu nedenle bu kurumlarda çalışan öğretim elemanlarının mesleki gelişimi önem kazanmaktadır. Bu gelişimin temel hedeflerinden biri öğretim ve öğrenmeyi etkileyen faktörlerin önde geleni olan teknolojinin en etkin şekilde kullanılmasıdır. Bu çalışmada, yurtdışında teknoloji ile zenginleştirilmiş öğrenmeyi hedefleyen bir üniversitenin ögretim elemanı mesleki gelişim altyapısı gözlem ve görüşmelerle incelenmiştir. Nicel araștırma yaklaşı$m i$ ile öğretim elemanlarının kullandıkları teknolojik ortam, araç ve yöntemlere ilişkin veriler bir anketle toplanmıştır. Kurumda etkin temel girişimler, Öğretim Tasarımı Bölümü, Öğretim Elemanı Gelişim Komitesi ve Öğretim Elemanı Öğrenme Topluluklarıdır. Sonuçta öğretim üyelerinin, en çok çevrimiçi Öğrenme Yönetim Sisteminin kullandığ 1 ; materyallere erişim, ders etkinliklerini yönetmek ve öğrencilerle iletişimde yarar sağladıkları belirlenmiştir. Kendilerini geliştirmek için bir uzmana danışmayı daha çok tercih etmektedirler. Türkiye için önerilen, çevrimiçi eğitim ile öğretim elemanı geliştirme çalışmalarının ülkemizin kurumsal ve akademik yapısina uygun olarak ele alınmasıdır.

Anahtar Kelimeler: Öğretim Eleman Geliştirme, Teknoloji ile Zenginleştirilmiş Öğrenme, Çevrimiçi Eğitim, Bilgi Toplumu

\begin{abstract}
Education expanding from national boundaries to global boundaries and being knowledge community at the forefront of policies, in Turkey, not only quantitative but also qualitative raise in number of higher education institutions and students must be aimed. For this reason, faculty development in such institutions should be emphasized. One of the main goals of development should be learning to use technology efficiently for teaching and learning. In this study, a university abroad aiming for technology enhanced learning, with infrastructure for faculty professional development in place, has been investigated in this research using observations and interviews. The technological environment that is used by the academic staff is determined with quantitative research approach and data were collected via survey. Instructional Design Department, Faculty Development Committee, and Faculty Learning Communities were the three main initiatives in the institution. As a result, they were mainly using Online Learning Management System; where accessing materials, managing course activities and communicating with the students were the benefits they claimed. Also they preferred to consult a specialist to develop themselves. In Turkey, it is recommended to consider online faculty development efforts suitable to the institutional and academic infrastructure needs of our country.
\end{abstract}

Keywords: Faculty Development, Technology Enhanced Learning, Online Education, Knowledge Community

Yrd. Doç. Dr. Alev Elçi, Aksaray Üniversitesi İİBF, alevelci@aksaray.edu.tr

* Bu araştırma TÜBİTAK 2219 - Yurtdışı Doktora Sonrası Araştırma Burs Programı tarafından desteklenmiştir. 


\section{Giriş}

Bilgi toplumu olma yolunda ilerleyen Türkiye'de yükseköğrenime verilen önem arttıkça yükseköğrenim kurumlarının ve eğitim gören öğrencilerin sayıları artmaktadır. Bu eğitim ordusunun öğrenme gereksinimlerini karşılayacak donanımda öğretim elemanı gereksinimi de hızla artmaktadır. Üniversitelerin gelişmesinde en önemli rolü olan öğretim elemanlarının temel görevleri kendilerini akademik ve pedagojik alanda geliştirmeleridir. Ancak, artık teknolojiyi günlük yaşamında kolaylıkla ve sıklıkla kullanan öğrenciler; eğitimleri sırasında teknolojinin getirdiği üstün olanakları da kullanmaya hazırdır. Bunların sonucunda öğretim elemanlarının teknoloji destekli eğitim konusunda kendilerini geliştirmeleri önem kazanmaktadır. Türkiye'de üniversitelerin gelişmesinde ve kalitelerini yükseltme çabalarında başta Yükseköğretim Kurulu (YÖK) ve Türkiye Bilimsel ve Teknolojik Araştırma Kurumu (TÜBİTAK) olmak üzere birçok kurum çalışmalar yapmakta ve teşvikler vermektedir.

$\mathrm{Bu}$ araştırmanın amacı, öğretim elemanlarının teknoloji ile zenginleştirilmiş öğrenme konusunda kendilerini geliştirmeleri için ABD'de bir üniversitede yapılan etkinlikler ile kullandıkları teknolojik araçların belirlenmesi ve yararlarının irdelenerek sonuçlar çıkarılmasıdır. Türkiye’ de öğretim elemanlarının mesleki gelişimi konusunda bazı durum tespiti çalışmaları yapılmıştır, ancak yurtdışında yükseköğretim kurumlarında öğretim elemanı geliştirme girişimleri irdelenmemiştir. Bu çalışmanın sonuçlarının Türkiyede henüz az sayıda üniversitenin yürüttüğü öğretim elemanı mesleki gelişimi etkinliklerine ilişkin diğer üniversitelerin stratejik planlarında yeni bir yapılanma girişimine katkısı olacağı beklenmektedir.

\section{Türkiye'de Yükseköğretimin Yapılandırılması}

Türkiye'de yükseköğretime olan talep fazlalığı yıllardır birçok öğrencinin üniversitelerin kapılarından geri dönmesine ve kazanamayanların yığılmasına yol açmıştır. Çözüm olarak 2006 yılından itibaren yüze yakın "genç" devlet ve vakıf üniversitesi açılmıştır. Üniversite sayılarının artması ile birlikte kontenjanlar artırılmış, yükseköğretime devam etme olanağı sağlanan öğrenci sayıları da 962,000 civarına yaklaşmıştır (Çetinsaya, 2014; ÖSYS, 2016). Bunun sonucu olarak 2015-2016 dönemi verilerine göre Türkiye yükseköğretim kurumlarında 6,5 milyondan fazla öğrenci eğitim görmektedir (YÖK, 2016). Yurtiçindeki öğrenci- lerin yanı sıra, YÖK "Study in Turkey” teması ile uluslararasılaşma çalışmalarına hız vererek yurtdışından gelen 72,000 den fazla öğrenciye de yükseköğretim olanağ1 sağlamaktadır. Bu öğrencilere eğitimini üstlenen öğretim üyesi ve görevlisi sayısı genel toplamda 85,000' e ulaşmıştır.

$\mathrm{Bu}$ gelişmelerin sonucunda yükseköğretimin yeniden yapılandırılması önem kazanmış ve bu doğrultuda üniversitelerdeki eğitim kalitesini arttırmak için birçok girişimler yapılmıştır. Bunların arasında araştırma görevlileri için yerleşik üniversitelerin sürdürdüğ̈ “Öğretim Üyesi Yetiştirme Programı - ÖYP” ve "Bilim İnsanı Yetiştirme Programı - BİYEP" in yanı sıra YÖK ve TÜBİTAK’n yurtdışında akademik gelişim için sağladığı burs olanakları vardır.

Çetinsaya (2014) önümüzdeki dönemde Türkiye'de yükseköğretime yönelik toplumsal talebin artacağ1nı ve büyümenin hızla devam edeceğini vurgulayarak "Hem bu büyümeyi sürdürülebilir kılmak hem de yükseköğretimin kendisinden beklenen nitelikli eğitimi ve araştırmaları yapabilmesi için nitelikli araştırmacı ve eğitimcilere ihtiyaç vardır." (s. 91) demektedir. Aynı kaynağa göre üniversitelerdeki öğrenci sayısı ile öğretim elemanları sayısı doğru oranda artmayarak, yıl geçtikçe öğretim elemanı başına düşen öğrenci sayısı fazlalaşmaktadır. Bu nedenle YÖK nezdinde öğretim elemanların geliştirilmesi ile ilgili yukarıda sözü edilen bir takım girişimler vardır. Ancak bu çalışmalar daha çok akademik disipline ilişkin gelişmeler olup, öğretim elemanlarının öğretim/öğrenme ve yeni eğitim teknolojileri kullanımı ile ilgili mesleki geliştirilmesi arka planda kalmaktadır.

\section{Teknoloji ile Zenginleştirilmiş Öğrenme}

Yabancı ülkeler özel kurumlar kurarak ve fonlar sağlayarak teknoloji destekli eğitimi geliştirme politikaları saptamaktadır. Bunlara bir örnek olarak "Teknoloji ile Zenginleştirilmiş Öğrenme - TZÖ” (Technology Enhanced Learning - TEL), İngiltere Yüksek Öğrenim Fonları Konseyi (Higher Education Founding Council for England - HEFCE) tarafından yükseköğretimde eğitimin en temel bileşeni olarak belirtilmiştir. Hazırladıkları raporda etkin öğretim, öğrenme, ölçme ve değerlendirme sürecini hedefleyen kurumların; temel altyapı ve uygulamaları ile uyumlu ve uygun teknolojilerin desteğiyle kendilerini nasıl geliştireceklerini belirlemeleri gerektiği vurgulanmaktadır. $\mathrm{Bu}$ yol haritasının çizmek; öğrencilerin beklentilerini 
karşılamak, küresel çekişmenin getirdiği zorlukları aşmak, artan öğrenci çeşitliliklerine hizmet vermek için hayati bir önem taşımaktadır. Ayrıca rapora göre güdüleyici bir rolü olan yeni ve gelişen teknolojilerin okulda, iște veya evde olanaklar sağlayarak etkin öğrenme ve yenilikçi düşünmeyi geliştirdiği belirtilmiştir. "Geleneksel e-öğrenme kapsamı dışında kalan; mobil cihazların iș-tabanlı öğrenmede ve portfolyo geliştirmekte kullanılması, eğitim içeriği geliştirmek ve kullanım sürekliliğinin sağlanması, öğrenme alanı tasarımı, değişik amaçlarla ders bilgilerini standartlaştırması ve sanal araştırma ortamlarının hazırlanmas1; gerçekte hepsi teknoloji desteğiyle öğretim ve öğrenmeyi geliştirmektir." HEFCE (2009, s. 8). Çağıltay (2010) TZÖ ortamlarının üstünlüğünü “...bilgisayar temelli öğrenme sistemi türü yaklaşımların başarılı olmaması nedeni ile günümüzde çalışmalar daha çok Teknoloji ile Zenginleştirilmiş Öğrenme (TZÖ) ortamlarına yönelmiştir. Bilgisayar temelli benzetim sistemleri ve bilgisayar oyunları, öğrenme ortamlarını zenginleştirme özellikleri nedeni ile TZÖ' lerde yaygın olarak kullanılmaktadır." şeklinde vurgulamıştır.

\section{Öğretim Elemanlarının Mesleki Gelişimi}

Öğretim elemanının öğrenmesi konusunda temel olan birçok mesleki öğrenme kuramı vardır. Bunların en önemli ortak noktası yetişkin eğitim kuramlarına dayanmasıdır (Lawler ve King, 2000). Yetişkin eğitiminin ünlü kuramcılarından biri olan Malcolm Knowles’a (1984) göre yetişkin eğitiminin etkili olması için tasarlanmadan önceden yetişkinlerin gereksinmelerin, inançların, önceki tecrübelerinin ve bulunduğu kariyer devresinin göz önüne alınması gerekir. Kuramlardan bir diğeri olan deneysel öğrenme ise uygulayarak öğrenmeye odaklanmıştır. Değişik öğrenme stilleri üzerinde yoğunlaşan David A. Kolb’un (1984) deneysel öğrenme modeli, sürekli eğitim ve resmi olmayan eğitim gibi yetişkin öğrenme kuram ve uygulamalarında kullanılmaktadır. Yapısal öğrenme kuramları da temeldir, çünkü öğretim elemanlarının zamanları çok değerli olduğu için öğrenme alanları, zaman ve yer seçimlerinde esnek olunması tercih edilmektedir. Layne vd. (2004) göre yapısal paradigmalar öğretim elemanlarının kendi öğrenme, öğretim, ölçme ve değerlendirme kuramlarını kurgulamalarını sağlar. Ayrıca Sorcinelli vd. (2006) öğretim elemanı gelişiminin mutlaka bağlantı, iletişim ve işbirliğine yönelik bir yapıda olmasını önermektedirler.
ABD'de 1975 yllında kurulmuş olan Yükseköğretimde Mesleki ve Kurumsal Gelişim Ağ 1 (Professional and Organizational Development Network in Higher Education - POD) öğretim elemanlarının gelişimini öğretmenlik, bilim adamlığı ve insanlık vasıflarının bütünleşmesi olarak görmektedir. Brew ve Boud (1996) gelişime bütüncül (holistic) yaklaşımı; bireylerin gereksinimlerini ve çalışma huzurlarını ön planda tutmak, kişisel, mesleki ve örgütsel gelişimlerine önem vermek, iş hayatındaki değişebilen tüm rolleri kabullenmek olarak tanımlamaktadırlar.

Öğretim elemanları genel olarak kendilerini bireysel ve içgüdüsel olarak geliştirirler. Sonradan bu gelişim daha kurumsal bir yapıya oturtularak resmileştirilmeye başlanmıştır. Mesleki gelişim kavram olarak uluslararası alanyazında bazı ufak anlam farklılıklarıyla: personel gelişimi, eğitim gelişimi, öğretim gelişimi, akademik gelişim, öğretim elemanı gelişimi gibi değişik isimler ile anılmıștır (ICED, 2006). Soran, Akkoyunlu ve Kavak (2006) tarafından ise eğitimde gelişim; öğretim, öğrenme ve müfredat çalışmaları becerilerini geliştirmek ve hayat boyu öğrenmeyi öğrenmek olarak açıklanmıştır.

\section{Yükseköğretimde Mesleki Gelişimin Tarihçesi}

1960' lı yıllardan sonra öğretim elemanı geliştirme amaçları değişmiş, yeni yaklaşımlar ortaya çıkmış, yeni boyutlar ve yönlendirmeler önem kazanmıştır (Kisner vd., 1998; Gillespie, 2010; Sorcinelli vd., 2006). Sorcinelli vd. (2006) ise öğretim elemanı geliştirmenin tarihçesini kronolojik olarak inceleyip 1960'dan sonra her on yılda bir değişim gösterdiğini belirlemiştir. Bu ardışık aşamaları: bilim adamı çağı, öğretim çağı, gelişim çağı, öğrenme çağı ve yeni yüzyllı iletişim ağ 1 çağı olarak nitelendirmiştir. Bu kronolojik aşamalarda öğretim elemanının rolü ilk başta öğretmenlikten başlamış, sonra öğrenciliğe ve günümüze yaklaştıkça da işbirlikçi bir role dönüşmüştür.

1970 'li yıllarda uygulamalar ve programlar yoluyla sağlanan öğretim elemanı gelişim olanakları daha sonra, 1980'li yıllarda, mesleki gelişim alanına dönüşmüştür (Centra, 1976; Sorcinelli vd., 2006). 1990 'lı yıllardan sonra ise çalışmalar ulusal sınırları aşmış uluslararası boyutta yapılanan bazı çalışmalarla, Personel ve Eğitim Gelişimi Birliği (Staff and Educational Development Association - SEDA) ve Uluslararası Eğitimde Gelişim Birliği (International Consortium for Educational Development - ICED) ile hız kazanmıştır. 


\section{Yükseköğretimde Mesleki Gelişim Modelleri}

Öğretim elemanı mesleki gelişimine yönelik birçok yapı ve model geliştirilmiştir. Sürdürülebilir gelişim yapılarından bazıları öğretim elemanı gelişim merkezleri, öğretim ve öğrenme mükemmeliyet merkezleri, komiteler, sertifika programları, öğretim elemanı öğrenme toplulukları ve uygulama topluluklarıdır. Son yıllarda hem yeni öğrenme yaklaşımlarının hem de teknolojinin kullanıldığı "Öğretim Elemanı Öğrenme Toplulukları" (Faculty Learning Communities - FLC) ya da onu temel alan modeller daha sık kullanılmaya başlanmıştır. Cox (2004)'un geliştirdiği Öğretim Elemanı Öğrenme Topluluklarının felsefesi yetişkin eğitimi, deneysel öğrenme ve yapısal öğrenme kuramları üzerine kurulmuştur (Hubball ve Poole, 2003). Öğretim elemanının gelişimini sağlamak için kaynak temin edilir, disiplinlerarası eğitim sağlanır, farklı akademisyenler, disiplinler ve tecrübe düzeyine göre etkinlikler düzenlenir. Ayrıca toplulukların kurumsal merkezi bir yapıya dönüşerek; öğretim elemanlarının sürekli gelişmesi için kurumun seçimine bağlı olarak akademik ya da idari yapı altında oluştuğu "Öğretim Elemanı Gelişim Merkezi" (Faculty Development Center - FDC) vardır. Bunlar öğretim ve öğrenmeye ilişkin programların tasarlanması, geliştirilmesi ve araştırılmasını sağlar. Bunun yanı sıra seminer, çalıştay düzenleme ve öğretim elemanlarına rehberlik ve danışmanlık hizmetlerini sunarlar (Shephard, 2004).

Tüm bu değişik oluşumların amacı, öğretim elemanlarında yenilikçi öğretim ve öğrenme yöntem ve teknolojilerine ilişkin farkındalık yaratmak ve etkin kullanımlarını hedefleyerek, sürekli gelişimlerini sağlamaktır. Zaman zaman "yalnız öğretmen" ve "yalnız kurt" (Sherer, Shea ve Kristensen, 2003; Cox, 2004) olarak anılan öğretim elemanlarının gelişimi için Harland ve Staniforth (2003) Bilgi ve İletişim Teknolojileri (BİT) kullanımını çok uygun bir seçenek olarak önermektedir. Böylece kendi soyutlanmış dünyalarını da koruyarak topluluklarda yer almaları mümkün olabilir. Bu amaçla çeşitli çevrimiçi mesleki gelişim modelleri geliştirilmiştir. Çevrimiçi öğretim elemanı gelişim çalıştayları ilk örneklerden sayılabilir (Blyth ve Rainbolt, 2006). Internete her yerden erişim ve kullanım kolaylığı ile teknoloji destekli sanal ortamlar gündeme gelmeye başlamıştır. Bunların bazıları, tartışma olanakları, çeşitli meslektaşlar arasında işbirliği etkinlikleri, uzman ve rehberler, çevrimiçi misafirler, değişik etkileşim biçimleri, bire-bir çalışma, bireysel projeler, e-rehberlik hizmetleri ve çevrimiçi seminer ve konferans etkinlikleri olarak sayılabilir. Bunların yanı sıra Web 2.0 olanakları olan Web seminerleri, blog, mikro blog, yayıncilık (podcast) ve wikiler kullanılabilir. Teknoloji kullanımını yaygınlaştırmak için mesleki geliştiriciler, öncelikle kullanılabilecek eğitim teknolojileri hakkında öğretim elemanlarına farkındalık kazandırmalıdırlar (Kiraz ve Özdemir, 2006). Lally ve McConnell (2005) çevrimiçi modellerin mesleki gelişim ağ için yadsınamaz öneminden söz ederken Taylor ve McQuiggan (2008) genelde eğitimlerin sadece beceri geliştirmeye yönelik olduğunu ve pedagojik tarafına pek değinilmediğini eleştirmiştir.

Cox (2004) ve Dede (2003)'nin öğretim elemanı gelişim modelleri tecrübe ve temel bilgi paylaşımına dayanan Öğretim Elemanı Öğrenme Toplulukları modeli üzerine kurulmuştur. Dede'nin modeli yüzyüze ve sanal etkileşimi birlikte içermekte olup hem eşzamanlı (sanal medya, sohbet odaları, etkileşimli medya, vb.) hem de etkileşimli olmayan (çevrimiçi tartışma, vb.) kullanan öğrenme ortamlarıdır. Harmanlanmış öğrenme modellerinin salt yüz-yüze modellerle karşılaştırıldığında daha esnek, kolay erişilebilir ve güçlü etkileşimler kurulmasını sağladığı belirtilmektedir (Cox, 2004; Vaughan, 2004). Böylece salt öğretim elemanı topluluklarının yerine kurumlara bağlı küresel kaynaklar topluluğu ve bağlantılar oluşturulabilmektedir (Sherer vd., 2003). Dede (2003) bunu farklı şekilde, "bilgi iletişimi"nden "bilgi yayma işbirliği” ne bir dönüşüm olarak ifade etmiştir. Daha sonraki ylllarda eğitim alanında bu tür hem resmi (formal) hem de resmi olmayan (informal) toplulukların sayısı hızla artmıştır (Field, 2005).

\section{Dünyada ve Türkiye'de Yükseköğretimde Mesleki Gelişim}

Öğretim elemanı gelişimine ilişkin araştırmaların dört grupta toplandığı görülmüştür: birinci grup yapılan mesleki gelişim modellerinin sunulması; ikincisi geliştiriciler için mesleki gelişimi planlama ve tasarlamaya yardımcı olacak etkinlikler, gereksinimler, inançlar, hedefler, beklentiler ve değerlerin ölçülmesi; üçüncüsü süregelen mesleki gelişim etkinliklerini biçimlendirici ölçme ve değerlendirilmesi, ve son olarak da bunların öğretim elemanı gelişiminde etkililiğinin saptanması. 
Centra (1976) ABD’ de yaklaşık iki bin yükseköğretim kurumunda yaptı̆̆ 1 araștırmada kurumların \%60'ında öğretim elemanı gelișimi programının bulunduğunu ya da benzer etkinliklerin yapıldığını saptamıștır. Bu araştırmada katılımcılar, seminerler ve çalıştaylardan daha fazla yarar sağladıklarını belirtmişlerdir. Mesleki gelişim oluşumunun ivme kazandığ 1990' lı yıllardan itibaren konferanslar katılımcıların yarar sağladıkları etkinliklerin başında gelmiştir (Sydow, 1993; Ferman, 2002). Benzer şekilde Odabaşı (2003)'nın araştırmasında çalıştaylar tercih edilmiştir.

Türkiye'de Moeini’nin (2003) Orta Doğu Teknik Üniversitesinde yaptığ 1 araştırma sonucunda araştırma asistanlarının \%72.5, öğretim elemanlarının \%57.6 oranı mesleki gelişim etkinliklerine katılmak istediklerini söylemişlerdir. Benzer şekilde Anadolu Üniversitesi eğitim fakültesinde yapılan bir çalışmada öğretim elemanları ve araştırma asistanları gelişime gereksinim duyduklarını belirtmişlerdir (Odabaşı, 2003; Kabakçı ve Odabaşı, 2008). Wallin ve Smith (2005) ABD'de meslek teknik okullarında yaptıklar1 araştırmada, öğretim elemanları mesleki gelişim etkinliklerinde kendilerini yeterli hissetmediklerini belirtmişlerdir.

Geleneksel öğretim ve öğrenmede teknoloji kullanı$\mathrm{m}$, çevrimiçi eğitim, teknolojinin sınıf ortamıyla bütünleşmesi gibi mesleki gelişim etkinlikleri en çok yapilan etkinliklerdir (Eddy, 2007). ABD ve Kanada'da Öğretim Elemanı Öğrenme Toplulukları olan 165 akademik kurumda yapılan bir araştırmada, benzer şekilde Richlin ve Essington (2004) en çok yapilan etkinliklerin öğretim ve öğrenme ve teknoloji konusunda olduğunu raporlamışlardır.

Öğretim elemanlarının etkili öğrenmesinde alanyazında çok önemli olduğu vurgulanan "gereksinimlerin belirlenmesi” ne ilişkin birçok araştırma vardır. Bunlardan biri olan Odabaşı (2003)'nın yaptığı çalışmada öğretim elemanları teknoloji kullanımı konusunda kendilerini geliştirmek istediklerini belirtmişlerdir. Sydow (1998), 1993 yılında yaptığı çalışmayı izlemek amacıyla yaptığı ankette "derslerde teknolojideki gelişimleri destekleyecek şekilde değişiklik yapma" etkinliğine katılma oranı da oldukça yüksek çıkmıştır. 21. yüzyılın gelmesi ile birlikte araştırmaların bulgularında daha çok teknoloji tabanlı gelişim etkinlikleri yer almaya başlamıştır. McQuiggan
(2007) çalışmasında, çevrimiçi dersler verecek öğretim elemanları kendilerini geliştirmek için "çevrimiçi ders geliştirmek için uygun teknolojileri seçebilmek" ve "çevrimiçi tartışmaları yönlendirebilmek" konularında gereksinim belirtmişlerdir. Doğu Akdeniz Üniversitesi'nde de öğretim elemanları ise gelişim için en fazla öğretim teknolojilerine ilişkin etkinliklere gereksinim duyduklarını belirtmişlerdir (Elçi ve Yaratan, 2012).

Ferman (2002), Avustralya'da bir üniversitede farklı tecrübeye sahip öğretim elemanlarının, katıldıklar1 yapısal öğrenme yaklaşımı ile yapılan gelişim çalışmalarının içinde işbirlikçi çalışmaları daha çok yararlı buldukları belirlemiştir. ABD de yapılan bir çalışmada öğretim elemanları gelişim için "öğrencilerin kritik düşünmesi” ve "öğrencilerin öğrenmesini destekleyecek teknolojilerin öğrenilmesi"ni en önemli konular belirtmişlerdir (Saena, 2003). Diaz, Santaolalla ve Gonzalez (2010) yaptıkları çalışmada Avrupa Yükseköğretim Alanına (European Higher Education Area - EHEA) girme yolundaki engelleri aşmak amacı ile bir mesleki gelişim modeli tasarlamak için İspanya'daki kurumlarda öğretim elemanlarının gereksinmelerini sorgulamışlardır. Araştırma sonucunda öğretim elemanları, mesleki gelişime katılırlarsa öğretim becerilerinin gelişeceğini, bireysel gelişimlerinin sağlanacağını ve değişime hazır olacaklarını belirtmişlerdir. Gereksinme olarak "yenilikçi öğrenme modellerini kullanmak" ve "öğrencilerin kritik düşünmelerini sağlamak" konularında gelişim belirtilmiştir.

Çevrimiçi öğretim elemanı gelişim programlarının etkinliğine ilişkin önemli araştırmalar bulunmaktadır. Villar Angulo ve Alegre de la Rosa (2007) ise çevrimiçi yapılan bir yenilikçi öğretim elemanı geliştirme programı sonunda tutumların değiştiğini belirtmiştir. Yaptıkları araştırmanın sonucunda Gregory ve Salmon (2013) çevrimiçi öğretime yönelik mesleki gelişimin etkili, yeterli, ölçeklenebilir ve sürekliliği sağlanabilir olması için ana prensipleri belirtmişlerdir. Bilgiç, Doğan ve Seferoğlu (2011) araştırmaları sonucunda öğretim elemanlarının çevrimiçi eğitimde en çok duydukları eksiklikleri pedagojik ve teknik konular, içeriğin hazırlanması ve kullanım desteği olarak belirtmişlerdir.

Randall’a (2008) göre öğretim elemanı gelişimi, yükseköğretimde kurumsal etkililiği arttırmak için en 
vazgeçilmez unsurdur ve kurum bunu ne kadar çok destekler ise öğrenci etkililiği ve güdülenmesi o kadar artacaktır. Aynı kaynak, öğretim elemanı gelişiminin; sadece öğrenciye değil öğretim elemanlarına da dayanma gücünün (vitality) artması, pedagojik formasyon, yenilikçi öğretim yöntemleri ve eğitim bilimi konularında bilgilenme gibi değerli getirileri olduğunu belirtmiştir. Üstelik mesleki gelişimin, yenilikçi teknolojilerin etkili kullanımına katkıda bulunmanın yanı sıra kaliteli eğitim ve öğretim programları hazırlanmasını da sağladığını açıklamıştır.

Bu çalışmada, ABD'de teknoloji ile zenginleştirilmiş öğrenmeyi hedefleyen Roger Williams Üniversitesi (RWU) nin öğretim elemanlarının mesleki gelişimi amacıyla kurumsal olarak hazırlanan altyapı ve öğretim elemanlarının kullandığı ortam, araç ve yöntemleri belirlemek amaçlanmıştır. Araştırmada aşağıdaki soruların yanıtları aranmıştır:

1. RWU tarafından yürütülen öğretim elemanlar1nın geleneksel eğitimden teknoloji ile zenginleştirilmiş öğrenmeye geçişe yönelik mesleki gelişim etkinlikleri ve programları nelerdir?

2. Öğretim elemanlarının teknoloji ile zenginleştirilmiş öğrenmeye ilişkin beceri, tecrübe ve alg1ladıkları yararlar nelerdir?

3. Öğretim elemanları eğitim amaçlı hangi teknoloji ile zenginleştirilmiş öğrenme yöntemleri ve araçları kullanıyorlar?

\section{Yöntem}

$\mathrm{Bu}$ araştırma genelleme yapmayı amaçlamaması boyutuyla betimsel bir çalışmadır. Mevcut bir durumu olduğu gibi betimlemeyi, yani araştırmaya konusuna dahil olan olayları, bireyleri, fiziksel ortamları ve özellikleri olduğu gibi araştırmayı ve belirlemeyi hedefleyen bir yaklaşım (Büyüköztürk vd., 2013) oldugu için seçilmiştir. Bu araştırmanın evrenini Bristol, Rhode Island (ABD) de Roger Williams Üniversitesinin (RWU) öğretim elemanları oluşturmuştur.

Araştırmada nicel araştırma deseni uygulanmıştır. Nicel yaklaşım genelleme ve saptamalarda bulunmaya yaramaktadır. Öncelikle belge incelemesi yapılmıştır. Elektronik ortamda ve diğer yazılı belgeseller araştırılarak, gözlem ve görüşmeler yaparak nicel veri toplanmış ve çözümlenmiştir. Böylece araştırmacının araştırdığı olguyu etraflı ve detaylı bir şekilde gözlemleyerek konuyu betimlemesi sağlanmıştır. Günümüzde öğretim elemanlarının yoğun çalışma temposu ve değişken çalışma saatlerinden dolayı basılı anketlerin dağıtılma ve toplanma zorluğu göz önüne alınarak, her zaman ve her yerden erişebilecekleri bir çevrimiçi anket formu Qualtrics ile tasarlanmıştır. Çevrimiçi anket aracılığıyla toplanan öğretim elemanlarının bireysel algılarına ilişkin nicel veriler yine Qualtrics toplanmış ve çözümlenmiştir.

Araştırma soruları 1 ve 2 için veri toplama yöntemi olarak RWU'da yapılan öğretim elemanı gelişim etkinliklerine ilişkin basıll, elektronik ve sözlü bilgiler toplandı. Bunlardan ilk ikisi için Öğretim Tasarımı Bölümünün önceki yıllarda hazırlanan raporları, 2012 yılında yaptıkları anket sonuçları ve Web sitesindeki bilgiler derlendi. Bu süreçte birlikte çalışma yürütülen RWU'daki araştırmacılarla düzenli haftalık toplantılar yapıldı. Benzer şekilde akademik yöneticilerle de görüşmeler yapıldı, onların bilgi ve görüşleri alındı. Görüşme yapılanlar Rektör Yardımcısı (Provost), Ortak Öğrenme ve İşletme Fakültesi dekanları, Öğretim Elemanı Gelişim Komitesi başkanı ve üyeleri, bazı ögrretim üyeleridir. Aslında bu görüşmeler araştırma planında öngörülmemiş olduğu halde yöneticilerden gelen istekler doğrultusunda başlatılmıştır. Ayrıca, görüşülen bir kişinin önerdiği diğer kişiler ile görüşmeler yapılmıştır. Bunlara ek olarak diğer bir değerli bilgi toplama fırsatı da yeni oluşturulan "Öğretim ve Öğrenmenin Gelişiminden sorumlu Rektör Yardımcısı Danışmanı” (Associate provost for the advancement of teaching and learning) pozisyonu nedeniyle ortaya çıkmıştır. Bu pozisyon için seçim sürecinde, üniversiteden isteyen herkesin katılabildiği açık düzen toplantılar düzenlenerek ilk elemeden geçen adayların öğretim ve öğrenmenin gelişimi konusunda RWU' ya yapacağı katkıları dinleme ve tartışma olanağı yaratılmıştır. Bu belge incelemeleri, gözlem ve görüşmelerin sonucunda 2009-2014 yılları arasında RWU' da yapılan tüm öğretim elemanı gelişim girişimleri analiz edilmiştir.

Sonuçta detaylı bir alanyazın taraması yapılarak ve RWU'da geçmişte yapılan anketler incelenerek “Teknoloji ile Zenginleştirilmiş Öğrenme için Öğretim Elemanı Gelişimi Anketi” (Faculty Professional Development for Technology Enhanced Education 
- FPDTEE) tasarlanmış ve geliştirilmiştir. Bu anket üçüncü araștırma sorusunu yanıtlamak amacıyla öğretim elemanına destek olan teknoloji ile zenginleştirilmiş öğrenme ortam, araç ve yöntemlerini belirlemek için hazırlanmıştır. Dört bölümde toplam 16 sorudan oluşmaktadır: demografik, gereksinmeler, destek ve açık uçlu sorular. Öğretim elemanlarının algılamaları ve RWU tarafindan verilen teknolojik hizmetleri kullanıma verdikleri önem beşli Likert Ölçeği kullanılarak çok yüksek (=5) ve çok düşük (=1) olacak şekilde sorgulanmıştır.

\section{Bulgular}

Araştırma sürecinde ilk olarak RWU üst yönetimince hazırlanan taslak vizyon tanımı incelenmiştir. Çünkü Diaz vd. (2010) hazırlanacak öğretim elemanı geliştirme programlarının kurumsal stratejilerle örtüşmesini önermektedirler. RWU vizyonunda temel değerleri içinde "katılımcı öğretim ve öğrenme ile toplumu güçlendirmek" bulunmaktadır. Rhoades'in (2012) dediğine göre "Öğrenci katılımcilığını ve elde ettiklerinin artırılmasını hedefleyerek yapılan yenilikçiliklerin çoğu yeni teknolojilerin içine öğrenmeyi sağlamak ve öğretim yapmayı sağlamak için gömülüdür." RWU'nun geleceğe bakıș açısını inceledikten sonra yürüttüğü öğretim elemanı mesleki gelişim etkinlikleri ve programları için belge inceleme, gözlemler ve görüşmeler yapılmıştır. Böylece birinci ve ikinci araştırma sorularını yanıtlanmıştır.

RWU öğretim elemanı geliştirme stratejilerine göre başlica üç mesleki gelişim girişimi bulunuyor (Şekil 1). Bunlardan birincisi, "Ortak Öğrenme" (Learning Commons) biriminde bulunan Öğretim Tasarımı Bölümüdür (Department of Instructional Design - ID). Bu bölümün yanı sıra kütüphanenin ve Bilgi Teknolojileri Destek Servisinin (BT) (Information Technology Support Services - IT) bağlı olduğu Ortak Öğrenme birimi kütüphane binasında dekanlık olarak temsil ediliyor. Öğretim Tasarımı bölümü, öğretim elemanlarının mesleki gelişimini sağlıyor. Bu bölümün amacı teknoloji ile zenginleştirilmiş öğrenme konuları ile ilgili kaynaklar, destek ve eğitim olanakları sunmaktır.

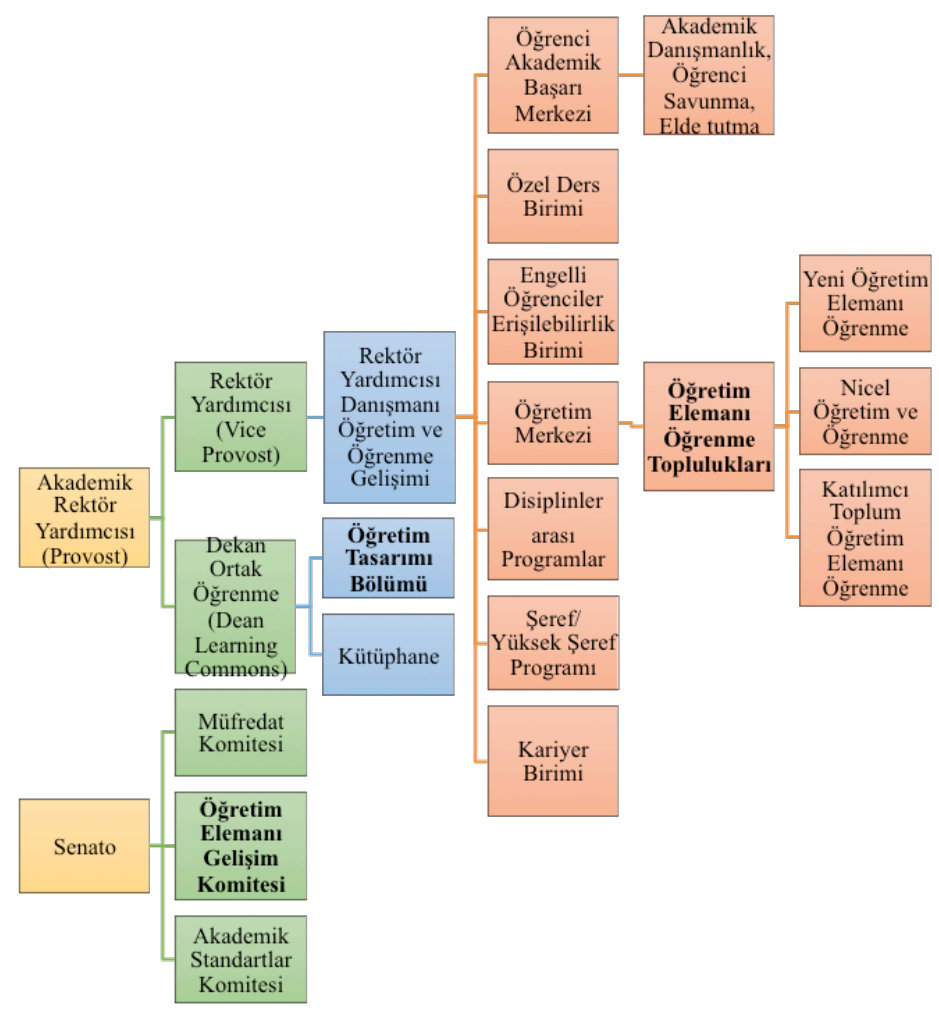

Şekil 1. RWU Öğretim ve Öğrenme Girişimleri Organizasyonu 
Öğretim Tasarımı bölümü çalışanları, Bilgi Teknolojileri Destek Servisi ile eğitim teknolojisi desteği ve eğitim kaynakları temini için eşgüdümlü olarak çalışıyor. Bölüm toplu eğitimin yanı sıra sorun gidermek, destek olmak, bireysel çalışmalar yapmak yoluyla öğretim elamanlarına yardımcı oluyor. Öğretim Tasarımı bölümünün düzenledikleri teknoloji ile zenginleștirilmiş öğrenmeye yönelik öğretim elemanı geliştirme etkinlikleri Şekil 2'de özetlenmiştir. Düzenledikleri birçok etkinliğin içinde sürdürülebilirliği sağlanan iki temel etkinlik "Çevrimiçi Eğitim Kısa Kursu" (Teaching Online Short Course) ve "Öğretimde Yenilikçi Akımlar" (Innovations in Teaching) serileridir.

\begin{tabular}{|c|c|c|}
\hline \multicolumn{2}{|c|}{ Eğitimin adı } & Ĕgitimin Türü \\
\hline \multicolumn{3}{|c|}{ Multimedya Öğrenme Materyalleri } \\
\hline & $\begin{array}{l}\text { Bridges, GoToTraining | GoToMeeting, iRubric, Panopto, Poll Everywhere, } \\
\text { Mobile, Multimedia Streaming Options, Qualtrics, rCloud, Other software }\end{array}$ & $\begin{array}{l}\text { TZÖ için video gösterimler } \\
\text { ve eğitimler }\end{array}$ \\
\hline \multicolumn{3}{|c|}{ Öğretim Tasarımı Bölümünün düzenlediği programlar } \\
\hline 1 & Teaching Online & Uzaktan eğitim \\
\hline 2 & Teaching Online & Uzaktan eğitim \\
\hline 3 & Teaching Online & Uzaktan eğitim \\
\hline 4 & Teaching Online & Uzaktan eğitim \\
\hline 5 & Teaching Online & Uzaktan eğitim \\
\hline 6 & $\begin{array}{l}\text { e-Teaching Academy:pedagogy and tools involved in teaching online \& hybrid } \\
\text { courses }\end{array}$ & Yüz-yüze Eğitim \\
\hline \multicolumn{3}{|c|}{ Öğretim Tasarımı Bölümünün düzenlediği diğer etkinlikler } \\
\hline 1 & Building community through sharing of faculty members teaching expertise & Sunum \\
\hline 2 & Blackboard & Yüz-yüze Eğitim \\
\hline 3 & $\begin{array}{l}\text { Academic and productivity software applications (not including E-Portfolio } \\
\text { Institute) }\end{array}$ & Uygulamalı çalıştay \\
\hline 4 & Sakai/Bridges pilot & Yüz-yüze Eğitim \\
\hline 5 & Panopto CourseCast lecture capture system & Yüz-yüze Eğitim \\
\hline 6 & Elluminate Live! Web Conferencing Course & Yüz-yüze Eğitim \\
\hline 7 & Elluminate Live! Web Conferencing Course & Yüz-yüze Eğitim \\
\hline 8 & Instructional development of fully online Nuclear Power engineering course & $\begin{array}{l}\text { Öğretim Elemanı Öğrenme } \\
\text { Topluluğu }\end{array}$ \\
\hline 9 & Use of e-portfolios and the new Sakai course management system & $\begin{array}{l}\text { Ŏgretim Elemanı Oğrenme } \\
\text { Topluluğu }\end{array}$ \\
\hline 10 & The E-Portfolio Institute & Yüz-yüze Eğitim \\
\hline \multicolumn{3}{|c|}{ Ögrretim elemanlarının düzenlediği Öğretimde Yenilikçi Akımlar Serisi } \\
\hline 1 & Writing Fellows Pilot Program & Sunum \\
\hline 2 & Think-Pair-Share \& Clickers in the Classroom & Sunum \\
\hline 3 & Using Qualtrics for Research: You, Your Students, and Your Classes & Sunum \\
\hline 4 & Using iPads in the Classroom & Sunum \\
\hline 5 & Applying Inquiry-Based Learning & Sunum \\
\hline 6 & Flipping Lessons in a College Course & Sunum \\
\hline 7 & Using Prezi to Promote Reflective Practice & Sunum \\
\hline 8 & Student Engagement, Interaction and Feedback & Sunum \\
\hline 9 & Fostering Student Reflections using Portfolios & Sunum \\
\hline 10 & Clogs, Blogs and Forums: Enhancing Communication and Collaboration & Sunum \\
\hline 11 & Organizing and Delivering an Online Course & Sunum \\
\hline 12 & $\begin{array}{l}\text { Mixing Elements of E-Portfolios with Upper-Level Chemistry Students: An } \\
\text { "Alchemist's Dream" or "No Reaction"? }\end{array}$ & Sunum \\
\hline 13 & $\begin{array}{l}\text { A Dynamic e-Duo: Creating Complementary Electronic Portfolios to Enhance } \\
\text { Student Learning }\end{array}$ & Sunum \\
\hline 14 & Take a Byte Out of Greek & Sunum \\
\hline 15 & Digital Manufacturing Integration with Architectural Design & Sunum \\
\hline 16 & Using Blackboard to Manage Undergraduate and Graduate Courses & Sunum \\
\hline 17 & Are They Getting This? & Sunum \\
\hline 18 & Just Click: Assess and Engage & Sunum \\
\hline 19 & Simple Screen Casting & Sunum \\
\hline 20 & Video as a Field R\&D Tool: A User's Guide & Sunum \\
\hline
\end{tabular}

Şekil 2. RWU 2009-2014 Öğretim ve Öğrenme Etkinlikleri Çizelgesi 
Çevrimiçi eğitimin kullanımını yaygınlaştırmak için her yıl bir ya da iki kez açılan Çevrimiçi Eğitim Kısa kursuna katılımın azlığı konusunda Öğretim Tasarımı bölümünün çıkmazları vardı. Bunun üzerine araştırmacının da katıldığı dönemde, kurs çevrimiç̧i yerine harmanlanmış yöntemle ilk hafta ve son hafta yüz-yüze devamı çevrimiçi olacak şekilde yapıldı. Bu sürekli eğitimlere paralel olarak Öğretimde Yenilikçi Adımlar serisi ile teknik ya da akademik konularda kendileri, bir uzman, farklı disiplinlerden kendi konularında teknolojik yenilikleri uygulayan öğretim elemanlarına seminerler verilmesine aracı oluyorlar.

İkinci öğretim elemanı geliştirme girişimi, önceden Senatoya bağlı olarak çalışan sonra Rektör Yardımc1sına bağlanan farklı disiplinlerdeki öğretim elemanlarından oluşan "Öğretim Elemanı Gelişim Komitesi" (Faculty Development Committee - FDC). Bu komite her yıl aktif olacak "Öğretim Elemanı Öğrenme Topluluk" larının belirlenmesini ve işleyişinin denetlenmesini sağlıyor. Böylece öğretim elemanı gelişimini sağlayarak öğrencilerin öğrenmesini iler- letecek benzer toplulukları kurmak isteyen öğretim elemanları Öğretim Elemanı Gelişim Komitesine başvuruyor. Başvuruda önerilerini, hedeflerini ve iş planlarını bir proje şeklinde hazırlayıp sunuyorlar. 2014-2015 okul yılında çalışan üç tane Öğretim Elemanı Öğrenme Topluluğu vardı. Bunlar sırasıyla Yeni Öğretim Elemanı Öğrenme Topluluğu (New Faculty Learning Community), Nicel Öğretim ve Öğrenme Topluluğu (Quantitative Teaching Learning Community) ve Katılımo Toplum Öğretim Eleman Öğrenme Topluluğu (Community Engagement Faculty Learning Community).

Üçüncü araştırma sorusu için hazırlanan FPDTEE anketi ile toplanan veriler Qualtrics ile analiz edilerek sonuçlar bulundu. FPDTEE anketini toplam 715 öğretim elemanından 142' si (\%20) yanitladı, bu sayının daha önceki benzer çalışmalardan çok daha iyi olduğu belirlendi. Yanttların birinci bölümündeki demografik bilgiler (akademik ünvan, fakülte/bölüm, eğitim tecrübesi, ders verme yöntemi, mesleki gelișime katılma durumu) listelenmiştir (Tablo 1). Buna göre

Tablo 1. Öğretim Elemanlarının Demografik Bilgilere Göre Dağılımı

\begin{tabular}{|c|c|c|}
\hline & $\mathrm{N}$ & $\%$ \\
\hline \multicolumn{3}{|l|}{ Akademik ünvan $(N=134)$} \\
\hline Tam zamanlı & 91 & 68 \\
\hline Yarı zamanlı & 43 & 32 \\
\hline \multicolumn{3}{|l|}{ Fakülte/ Bölüm $(N=136)$} \\
\hline Fen ve Edebiyat & 61 & 45 \\
\hline İşletme & 17 & 13 \\
\hline Sürekli Eğitim & 14 & 10 \\
\hline Mimarlık, Sanat ve Tarihi Varlıkları Koruma & 11 & 8 \\
\hline Mühendislik, Bilişim ve İnşaat Yönetimi & 9 & 7 \\
\hline Hukuk & 9 & 7 \\
\hline Adalet Çalışmaları & 7 & 5 \\
\hline Eğitim & 5 & 4 \\
\hline Diğer & 3 & 2 \\
\hline \multicolumn{3}{|l|}{ Eğitim tecrübesi $(N=136)$} \\
\hline $0-5$ y1l & 27 & 20 \\
\hline $6-10$ y1l & 21 & 15 \\
\hline $11-20$ y1l & 54 & 40 \\
\hline 20 y1l üzeri & 34 & 25 \\
\hline \multicolumn{3}{|l|}{ Ders verme yöntemleri $(N=136)$} \\
\hline Sınıf içi & 118 & 87 \\
\hline Çevrimiçi & 63 & 46 \\
\hline Harmanlanmış (Blended/ Hybrid) & 60 & 44 \\
\hline \multicolumn{3}{|l|}{ Mesleki gelişime katılma $(N=134)$} \\
\hline RWU içinde & 92 & 69 \\
\hline RWU dışında & 46 & 34 \\
\hline Katılmayan & 29 & 22 \\
\hline
\end{tabular}


katılımcılar arasında tam-zamanlı öğretim elemanları (\%68) çoğunlukta, kısmi-zamanlılar (\%32) azınlıktaydı. Tam-zamanlı katılımcilar, toplam tam-zamanlı öğretim elemanlarının \%38.63'ini, kısmi-zamanlı katılımcilarda toplam kısmi-zamanlıların \%8.09'unu temsil ediyordu.

Katılımcı öğretim elemanlarının en fazla Fen ve Edebiyat fakültesinden olması, bu fakültenin üniversitenin en büyük kapasiteli birimi olmasından dolayı doğal kabul edilebilir. Ancak o fakülteden olan katılımcıların tüm fakültenin sadece $\% 20$ ' sini temsil ediyordu. Buna karşın, İşletme Fakültesi ve Mühendislik, Bilişim ve İnşaat Yönetimi Fakültesi katılımcı öğretim elemanları ilişkin fakültelerin tüm öğretim elemanlarının \%25'i olarak daha fazla temsil edildi. Aynı zamanda bu iki fakültenin tam-zamanlı kat1lımcıları tüm tam-zamanlı öğretim elemanlarının \%40’nı temsil ettiği için daha çok katkıları olabilir.

Katılımcıların yarıdan fazlasının 10 yıldan fazla, \%40'inın 11-20 yıl arası eğitim tecrübesi vardı. Ders verme yöntemleri $\% 87$ sınıf-içi, \%46 çevrimiçi, \%44 harmanlanmış (blended/ hybrid) olarak belirtildi. $\mathrm{Bu}$ sonuçlar ile tüm teknolojik olanaklara karşın ka- tılımcıların tümüne yakın öğretim elemanının geleneksel sınıf-içi eğitim yöntemini kullanmayı sürdürdükleri saptandı.

Diğer bir demografik soru katılımciların program, seminer, çalıştay, vb. bir mesleki gelişim etkinliğine katılma durumlarını belirlemek amacını güdüyordu. Bildirimlere göre \%22 öğretim elemanı hiç gelişim etkinliğine katılmamış olduğu buna karşın \%69 RWU'da katılmış ve \%34 RWU dışında katılmış olduğu belirlendi. Herhangi bir etkinliğe katılmamış olanların dışındaki bazı öğretim elemanları hem kurum içi hem de kurum dışı etkinliklere katılmış olabilir.

İkinci araştırma sorusunu yanıtlamak için hazırlanan Tablo 2, öğretim elemanına destek olacak teknoloji ile zenginleştirilmiş ögrenmeye ilişkin algılanan beceri, tecrübe ve yararları belirlemek amacıyla oluşturulmuştur. Öğretim elemanlarının bu alanda beceri ve uzmanlık seviyeleri kendi bildirimlerine göre ortalamanın üstündedir $(M=3.41)$. Ayrıca, teknoloji ile zenginleştirilmiş öğrenmenin kullanılmasının ne tür yararlarının olduğunu ve önem derecesi belirlendi. Buna göre materyallere erişim $(M=4.29)$, ders etkinlikleri yönetimi $(\mathrm{M}=4.21)$ ve öğrenciler ile iletişimi arttırmak $(M=4.11)$ en önemli yararlar olarak bildirildi.

Tablo 2. Teknoloji ile Zenginleştirilmişöğrenmeye ilişkin Beceri, Tecrübe ve Algıladıkları Yararlar

\begin{tabular}{lccc}
\hline & $\mathrm{N}$ & $\begin{array}{c}\text { Aritmetik } \\
\text { Ortalama }\end{array}$ & $\begin{array}{c}\text { Ortanca } \\
\text { (Min-Mak) }\end{array}$ \\
\hline \multicolumn{1}{c}{ TZÖ beceri ve tecrübesi } & 133 & 3.41 & $(1-5)$ \\
\hline \multicolumn{1}{c}{ TZO kullanmanın yararlart } & & & \\
Materyallere erişim & 132 & 4.29 & $(1-5)$ \\
Ders etkinliklerini yönetme & 131 & 4.21 & $(1-5)$ \\
Öğrenciler ile iletişimi geliştirmek & 133 & 4.11 & $(1-5)$ \\
Öğretimi geliştirmek & 130 & 3.80 & $(1-5)$ \\
Öğrencinin öğrenmesini geliştirmek & 129 & 3.65 & $(1-5)$ \\
Zaman kazancı & 131 & 3.56 & $(1-5)$ \\
Öğrenciler arasında iletişimi geliştirmek & 115 & 3.34 & $(1-5)$ \\
\hline
\end{tabular}


Tablo 3. Öğretim Elemanlarının Teknoloji ile Zenginleştirilmiş Öğrenmeye Iilişkin Destek Alma Tercihleri

\begin{tabular}{lcc}
\hline \multicolumn{1}{c}{ TZÖ yardım } & N & $\%$ \\
\hline Bireysel olarak bir uzmana danışma & 98 & 73 \\
Çalıştay & 67 & 50 \\
Meslektaş ile resmi olmayan çalışma & 66 & 49 \\
Video gösterimi & 52 & 39 \\
Çevrimiçi eğitim & 47 & 35 \\
RWU Öğretim Tasarımı Web sayfası & 37 & 28 \\
Sanal seminer & 27 & 20 \\
Diğer & 7 & 5 \\
\hline
\end{tabular}

Öğretim elemanlarının kendi mesleki gelişimleri için ne tür destek almayı tercih ettikleri Tablo 3' de gözükmektedir. Buna göre yarıdan çok öğretim elemanı bir uzmanla birlikte danışarak (\%73), çalıştaylar (\%50) ve bir meslektaşla birlikte çalışarak (\%49) öğrenmeyi tercih etmiştir. Katılımcılar çevrimiçi eğitimle öğrenmeyi çoklukla seçmemişlerdir.
Üçüncü araștırma sorusunu yanıtlamak için Öğretim elemanlarının kullandıkları Teknoloji ile Zenginleştirilmiş yöntemler ve araçların sonuçlarından en çok seçilen beş tanesi Tablo 4' de sunulmuştur. Bu tablonun içerdiği ilk iki liste RWU'nun öğretim elemanlarına sunduğu olanaklardı. Üçüncü liste bunların dişında kalan ve öğretim elemanlarının kendi olanak-

Tablo 4. Öğretim Elemanları Tarafından Kullanılan Teknoloji ile Zenginleştirilmiş Öğrenme Ortam/ Araç/Yöntemler

\begin{tabular}{lcc}
\hline \multicolumn{1}{c}{ RWU olanakları (N=138) } & $\mathrm{N}$ & $\%$ \\
\hline Öğrenme Yönetim Sistemi (Bridges) & 133 & 96 \\
Kütüphane veritabanları (Library databases) & 81 & 59 \\
Video ortamı (Panopto) & 62 & 45 \\
Sanal toplantı (GoToMeeting/ GoToTraining) & 55 & 40 \\
İstatistiksel analiz (Qualtrics) & 43 & 31 \\
\hline \multicolumn{1}{c}{ Bridges içinde olanaklar (N=137) } & & 82 \\
Ders programı (Syllabus) & 113 & 80 \\
Öğrenci listesi (Rooster) & 110 & 80 \\
Ödevler (Assignments) & 109 & 79 \\
Kaynaklar (Resources) & 108 & 72 \\
Duyurular (Announcements) & 99 & 36 \\
\hline \multicolumn{1}{c}{ Ek olanaklar (N=94) } & & 36 \\
Dizgi/ Basım (Publisher materials) & 34 \\
Etkileşimli dosya paylaşımı & 34 & 36 \\
(Collaborative file sharing: Goggle Drive) & 34 & 29 \\
e-kitap (e-books) & 27 & 21 \\
Taşınabilir cihazlar (Portable devices) & 20 & \\
Kişisek Web siteleri (Personal website) & & \\
\hline
\end{tabular}


larıyla kullandıkları teknolojilerdi. Bu son liste aynı zamanda kurum tarafından öğretim elemanlarının kullanımına olanak sağlanması beklenilen teknolojiler olarak önerilebilir.

Hemen hemen tüm öğretim elemanları RWU Öğrenme Yönetim Sistemi (Learning Management System - LMS) Bridges (96\%) ve yarıdan fazlası Kütüphane veritabanlarını (59\%) kullanıyorlardı. Bridges Öğrenme Yönetim Sistemi içinde sunulan araçlardan Öğretim programı, Öğrenci listeleri, Ödevler ve Kaynaklar \%80 öğretim elemanı tarafından sıklıkla kullanılıyordu. Seçilenlerin derslerin işleyişine ilişkin öğrenciler ile bilgi alışverişini sağlayan araçlar olduğu dikkati çekmektedir. RWU sunduğu olanaklar dışında en sık (\%36) dizgi/ basım, etkileşimli dosya paylaşımı ve e-kitaplar kullanılıyordu.

\section{Tartışma ve Sonuç}

Bu çalışmada, 1956 yılında ABD’de kurulmuş olan Roger Williams University (RWU)'nin 2009 yllından bu yana teknoloji ile zenginleştirilmiş öğrenmeyi etkinleştirmek için öğretim elemanı gelişimi konusunda yaptığı çalışmalar ve öğretim elemanlarının kullandıkları ortam, araç ve yöntemler araştırılmıştır. Webometrics Dünya Üniversiteleri Sıralamasına göre RWU $^{1}$ ülkesi çapında 557 ve dünya çapında 2542 sıradadır. Üniversitede üç temel öğretim elemanı geliştirme girişimi vardır. Bunlardan birincisi olan Öğrenme Tasarımı Bölümü, öğretim elemanı yetiştirmek için kaynaklar, destek ve eğitim amaçlı etkinlikler düzenlemektedir. Bunlardan en önemlisi yılda bir ya da iki kez düzenledikleri 6 haftalık Çevrimiçi Eğitim Kısa Kursudur. Burada görüşmeler sonunda elde edilen bilgilere göre, gönüllülük esasına göre katılım sağlanan bu eğitim olanağından öğretim elemanlarının yeterince yararlanmadığ belirlenmiştir. Bu nedenle son dönemde çevrimiçinden harmanlanmış eğitime geçiş yapıldı. Öğretim elemanlarının önerdikleri ve seçilirse uygulamaya koydukları projelerin olduğu Öğretim Elemanı Öğrenme Toplulukları bir diğer gelişim girişimdir. Değişik disiplinlerden öğretim elemanlarının üyesi olduğu Öğretim Elemanı Gelişim Komitesi ise sözü edilen toplulukların projelerini seçen ve uygulama sürecinde kontrolünü yapan bir yapıyı oluşturuyordu. Önemli bir diğer gelişme de bunların bağlı olacakları yeni bir Rektör Yardımcısı Danışmanı po-

1 http://www.webometrics.info/en/search/Rankings/Roger\%20 Williams\%20University\%20type\%3Apais zisyonu açlarak öğretim elemanı geliştirmeye ilişkin Bölüm, Komite ve Toplulukların hepsinin ona bağlanması için yeni bir oluşum başlatıldı. Özellikle Ortak Öğrenme adını verdikleri kütüphanenin bağlı olduğu birimin, öğretim ve öğrenme konusunda çok etkin çalışmaları olduğu gözlemlenmiştir. Öncelikle çok büyük ve farklı olanaklar sağlayan bu kütüphane öğretim elemanlarının kendini geliştirmesi ve öğrencilerini yönlendirmesi için kaynak ve destek sağlayan önemli bir birimdir.

Öğretim elemanları kendi beceri ve uzmanlıklarını orta düzeyde yeterli algılamakla birlikte görüşmelerde en çok sözü edilen, yenilikleri ve teknolojiyi öğrenmeye, sorunları çıtığı zaman çözümlemeye ayıracak yeterince zamanlarının olmadığıydı. Bu arada öğretim elemanına verilen çevrimiçi eğitimin sorunlarından biri, Taylor ve McQuiggan’n (2008) dediği gibi, daha çok teknik kullanım detaylarının ve beceri geliştirmek üzerinde durulması olabilir. Ancak, burada iki durum ortaya çıabilir, eğer öğretim elemanı teknoloji becerileri zaten yeterli düzeyde ise, çevrimiçi eğitim için hazırlanan olanaklar doyum sağlamayabilir. Aksine Bilgiç vd. (2011) söz ettiği gibi pedagojik ve teknik eksikliklerden dolayı, teknoloji becerileri ve tecrübesi az olan bir öğretim elemanına da becerileri öğrenmek için daha fazla zaman harcamak zorunda kalabilir. Böylece eğitimlerin ve hatta materyallerin farklı düzeyde teknolojisi bilgisine göre hazırlanması uygun olabilir. Hatta istediği zaman ve yerde bireysel desteğin sağlanması gerekebilir. Bu, yetişkin eğitim kuramlarında kişinin zamanı yeterli olmaması nedeniyle esnek eğitim verilmesi görüşü ile örtüşmektedir. Anket yanıtlarından da görüldüğü gibi öğretim elemanları grup halinde çevrimiçi eğitim yerine uzmandan ya da arkadaşından bire-bir öğrenmeyi daha çok tercih etmişlerdir. Büyük çoğunluk Öğrenme Yönetim Sistemlerini kullanmaktadır, ancak en yoğun kullanımın ders programı ve öğrenci listeleri ile ilgili iletişim ve materyal paylaşımı olduğu görülmektedir.

ABD örneğini inceledikten sonra gelişmekte olan bir ülke konumundaki Türkiye’nin durumuna bakalım. Dünya Bankası (2000) raporunda gelişmiş ülkeler ve gelişmekte olan ülkelerin yükseköğretimi karşılaştırılmıştır. Yükseköğretimin iş hayatına yetenekli ve kaliteli iş gücü hazırlaması için kaliteli eğitim sistemleri gerekliliğinden söz edilmiştir. Rapora göre, eğitim, gelişmiş ülkelerin temel politikalarında öncelikli olduğu için gelişmiş ülkelerin bu konuda hızlı tepki verdiği savunulmuştur. Buna karşın gelişmekte olan 
ülkelerde yükseköğretim gören genç sayısının hızla artmakta olduğu fakat bu durumda bilgi ekonomisi ile rekabet etmelerinin mümkün olup olmayacağını, ileride dıșlanmanın artabileceği ve 21. Yüzyıl yeteneklerine sahip olamayacakları sorgulanmıștır. Yılmaz ve Kılıçoğlu (2013)'nun ifade ettiği gibi “Teknoloji ve ekonominin değişen doğası, eğitim organizasyonlarını hem yapısal hem de fonksiyonel açılardan değişmek zorunda bırakıyor" (s.19). Bu nedenlerle gelişmekte olan ülkelerin genç üniversiteleri vakit kaybetmeden teknoloji altyapısı (donanım, yazılım, ağ, vb.) tamamlayıp gelişmiş ülkelerden bilgi göçü yoluyla öğretim elemanlarının teknoloji ile zenginleştirilmiş eğitim konusunda gerçekleştirdiklerini elde etmelidir. Ancak, değişik ülkelerdeki yükseköğretim kurumlarının farklı eğitim sistemleri, stratejileri, müfredatları, kaynakları ve kültürleri olduğu bilinmektedir. Chism, Gosling ve Sorcinelli (2010)'nin önerdiği gibi “...gelişimle ilgili kişilerin öğretim elemanlarının ihtiyaçlarını; ki bunlar ABD deki öğretim elemanlarından oldukça farklı olabilir, anlayacak beceriler ve hassasiyetler geliştirmesi gerekir." (s. 244).

Son yıllarda gelişmiş ülkeler ile gelişmekte olan ülkelerin eğitim açısında birbiriyle bilgi paylaşmasını sağlamak amacıyla birçok çalışmalar yapılmaktadır. Türkiye'de; Erasmus ile Avrupa Birliği ülkeleri, Mevlana Programı ile Türki Cumhuriyetler, YÖK ve TÜBİTAK bursu ile ABD arasında öğretim elemanı değişimine olanak sağlanarak öğretim elemanlarının araştırma ve mesleki gelişimi burslarla desteklenmektedir. Genellikle bu bursların akademik gelişimlerini desteklediği, buna karşın hızla artan üniversite sayısı, öğretim elemanı sayısına karşın bu elemanların mesleki konularda gelişimleri yeterince ele alınmamıştır. Öğretim elemanı gelişiminin Türkiye için yeni bir ilgi alanı olduğundan ve öğretim elemanlarına sağlanan mesleki gelişim olanaklarının bulunmadığından daha önce söz edilmiştir (Odabaşı, 2003; Odabaşı, 2005). Bunun nedeni kurumların daha bu çalışmaların varlığının ve öneminin farkında olmaması olabilir. Son yıllarda öğretim elemanı geliştirme programları ile ilgili bazı öneriler yapılmış (Ünver, 2010) ve öğretim elemanlarının artık akademide değişen rolleri için hazır olmaları gerekliliğinden söz edilmiştir (Kızıltepe, 2010). Bu konuda hareketlilik gösteren bazı etkinlik örnekleri olarak Adnan Menderes Sürekli Eğitim Merkezi $^{2}$ aracıllığıyla açtı̆̆ı ve diğer üniversitelere de

2 http://www.akademik.adu.edu.tr/aum/sem/default. asp?idx $=313437$ duyurduğu "Temel Eğitim Becerileri” kursu ve Koç Üniversitesinin "Öğretim ve Öğrenme Ofisi (Office of Teaching and Learning - KOLT) ${ }^{3}$ eğitimleri gösterilebilir. KOLT öğrenci öğrenmesine destek olmak için öğretim elemanlarının derslerinde öğretim yöntemlerini sürekli olarak geliştirmeleri amaçlı birçok program hazırlamaktadır.

"Yükseköğretim kurumları öğretim elemanlarının kurumuna sadakatine dayanmaktadır. Onların öğrenciler ve meslektaşları karşısında varlığı ve hizmete hazır olması öğrenmeyi yüreklendiren bir ortam hazırlamaya çok etkili olmaktadır" (Dünya Bankası, 2000, s.27). Kurumda bu kadar önemli olan öğretim elemanlarına mesleki gelișim olanakları sağlanırsa dayanma güçleri artar ve teknolojiyi daha etkin kullanmaya başlarlar (Randall, 2008). HEFCE (2009)'nin vurguladığı gibi kurumsal altyapı ve uygulamalarla uyumlu teknolojiler seçilmelidir. Cox (2004) ve Vaughan vd. (2004) belirttikleri şekilde harmanlanmış öğretim elemanı geliştirme modelleri kullanılarak esnek, erişilebilir ve sağlam etkileşimler oluşturularak öğrenme süreci etkin kılınabilir. Türkiyede çevrimiçi eğitimi kullanan Anadolu Üniversitesi dünyada ilk sıralarda gelmesine rağmen (Dünya Bankası, 2000) diğer üniversitelerde bu kullanımın yeterince yaygın olmadığı görülmektedir. Salmon ve Angood (2013) teknoloji ile zenginleştirilmiş eğitim için dönüşüm gerektiğini söyleyerek üniversite yöneticilerine bu konuda önerilerde bulunmaktadır.

Yeni bir oluşuma başlamadan önce yetişkin eğitimi kuramlarının önerdiği gibi öğretim elemanlarının inançlarının ve gereksinimlerinin saptanması önerilebilir. Kurumsal olduğu gibi bölgesel olarak ta teknoloji ile zenginleştirilmiş eğitim ve öğretim elemanı gelişimi konularında farkındalık seminerleri düzenlenebilir. Özelde Aksaray Üniversitesi göz önüne alınırsa; Aksaray ile birlikte bölgedeki Niğde, Konya, Nevşehir, Kırşehir, Kayseri, Karaman illerindeki 9 devlet ve 5 vakıf üniversitesi ${ }^{4}$ de bu bilgi transferinden yararlanabilir. Burada önemli bir olgu, bu üniversitelerden ASÜ ve diğer 11 tanesinin kuruluş tarihinin on yll ve daha az olmasıdır. Böylece bu etkinlikler genç üniversitelerdeki eğitim kalitesini arttırmak ve teknoloji ile zenginleştirilmiş eğitime firsat vermek için bir mihenk taşı olabilir. Son yıllarda hızla artan öğrenci sayıları ile derslerin bir kısmı salt uzaktan eğitim, bir kısmı harmanlanmış eğitim olarak yapılarak derslik ve çok

3 http://kolt.ku.edu.tr/tr/faculty/devel

4 http://yok.gov.tr/web/guest/universitelerimiz 
kalabalık sınıflar sorunlarının çözümlenmesine yarar sağlayacaktır. Bunların yanı sıra öğretim elemanları teknoloji destekli eğitim için çoklu medya (çizgi filmler, filmler, podcast, simulasyonlar, vb.) ve etkileşimli Web 2.0 olanakları (Wiki, sosyal ağlar, vb.) kullanmaları için gerekli altyapı donanım ve yazılım alımı, Internet ağının ve telsiz (WiFi) bağlantılarının güçlendirilmesine bir adım olacaktır. Öğretim elemanlarının farkındalıkları arttığı zaman; teknoloji konusunda yeterli ve istekli olanlar, yenilikçi girişimleri erken benimseyenler "öncü öğretim elemanı" olabileceklerdir. $\mathrm{Bu}$ çekirdek kadro, öğretim elemanı gelişimini sağlamak için Öğretim Elemanı Topluluklarını oluşturulabilecektir. Son söz olarak Dahlstrom’nn (2015) önemle vurguladığ elemanlarının teknolojiyi dersleriyle bütünleştirmelerini ve öğretim ve öğrenme teknolojilerini etkin kullanmalarını istiyorsa, öğrencinin ve öğretim elemanının teknoloji kullanım ve beklentileri ile kurumun altyapısını aynı çizgiye getirmeleri gerekmektedir.

\section{Teşekkür...}

Bu araştırma Türkiye Bilimsel ve Teknolojik Araştırma Kurumu (TÜBİTAK) 2219 - Yurtdışı Doktora Sonrası Araştırma Burs Programı tarafindan desteklenmiştir. Yazar, Dr. Farbod Farhadi ve Dr. Linda Beith (Roger Williams University), Dr. Malcolm Brown (EDUCAUSE Learning Initiative), Dr. Arif Altun (Visiting Fullbright Researcher, Harvard Graduate School of Education), Dr. Yasemin Yavuz (Ankara University Medical School), Dr. Yovanska Duarte-Velez (Brown University), Sarvnaz M. Gavami ve Ecem Elçiye teşekkür eder.

\section{Kaynakça}

Bilgiç, H. G., Doğan, D. \& Seferoğlu, S. S. (2011). Türkiyede yükseköğretimde çevrimiçi öğretimin durumu: İhtiyaçlar, sorunlar ve çözüm önerileri. Yükseköğretim Dergisi, 1(2), 80-87. doi:10.2399/ yod.11.080

Blyth, R. D., May, M. K. \& Rainbolt, J. G. (2006). Effective live online faculty development workshops: One Model. Educause Quarterly (4).
Brew, A., Boud, D. (1996). Preparing for new academic roles: A holistic approach to development. The International Journal for Academic Development, 1(2), 17-25. doi:10.1080/1360/44960010203

Büyüköztürk, Ş., Çakmak, E. K., Akgün, Ö. E., Karadeniz, Ş. \& Demirel, F. (2013). Bilimsel Araştırma Yöntemleri. Ankara: Pegem. ISBN: 9789944919289

Centra, J. A. (1976). Faculty development practices in U.S. colleges and universities. New Jersey: Educational Testing Service.

Chism, N., Gosling, D. \& Sorcinelli, M.D. (2010). International faculty development. K. Herr ve D. Robertson (Ed.), A Guide to faculty development, 243-258. San Francisco: Jossey-Bass. ISBN:978-0$470-40557-4$

Cox, M. D. (2004). Introduction to faculty learning communities. New Directions for Teaching and Learning, 97, 5-23. doi: 10.1002/tl.129

Çağıltay, K. (2010). Eğitim ve teknoloji: Bardak dolu mu boş mu ya da nasıl doldururuz? ÖDTÜ'lüler Bülteni, Mart 2010.

Çetinsaya, G. (2014). Büyüme, kalite, uluslararasılaşma: Türkiye yükseköğretimi için bir yol haritası. Yükseköğretim Kurulu Yayın No: 2014/2. Eskişehir: Anadolu Üniversitesi Yayınları. ISBN:978-978975-7916

Dahlstrom, E. (2015). Educational Technology and Faculty Development in Higher Education. Research report. Louisville, CO: ECAR, June 2015. Erişim https://library.educause.edu/resources/2015/6/educational-technology-and-faculty-developmentin-higher-education

Dede, C. (2003). Distributed-learning communities as a model for educating teachers. R. Ferdig vd. (Ed.), Proceedings of Society for Information Technology and Teacher Education International Conference 2004, (s. 3-12). Chesapeake, VA: AACE. 
Diaz, M. J. F., Santaolalla, R. C. \& Gonzalez, A. G. (2010). Faculty attitudes and training needs to respond the new European higher education challenges. Higher Education, 60 (1), 101-118.

Dünya Bankası (2000). Higher education in developing countries: Peril and Promise. The International Bank for Reconstruction and Development, Washington DC: The World Bank. ISBN: 0-8213-4630-X

Eddy, P. L. (2007). Faculty development in rural community colleges. New Directions for Community Colleges, (137), 65-76. doi:10.1002/cc.271

Elçi, A. \& Yaratan, H. (2012). Faculty Beliefs and Needs: Opening the Gate to ICT-based Professional Development in Teaching and Learning. Germany: Lambert Academic. ISBN: 978-3659313943

Ferman, T. (2002). Academic professional development practice: What lecturers find valuable. The International Journal for Academic Development, 7(2), 146-158. doi:10.1080/1360144032000071305

Field, J. (2005). e-mentoring. S. Fallows ve R. Bhanot (Ed.), The staff and educational development series (SEDA). Quality issues in ICT-based higher education. NY: RoutledgeFalmer. ISBN:0-415-33520-5

Gillespie, K. J. (2010). Organizational Development. Gillespie, K. J. ve Robertson, D.L. (Ed.) A guide to faculty development. CA: Jossey-Bass. ISBN:978-0470-40557-4

Gregory, J. \& Salmon, G. (2013). Professional development for online university teaching. Distance Education, 34(3), 256-270. doi:10.1080/01587919.2013 .835771

Harland, T., Staniforth, D. (2003). Academic Development as Academic Work. International Journal for Academic Development, 8(1/2), 25-35. doi:10.1080/1360144042000277919

HEFCE (2009). Enhancing learning and teaching through the use of technology: A revised approach to HEFCE's strategy for e-learning. Higher Education Founding Council for England. Erişim http://webarchive.nationalarchives.gov.uk/09_12.pdf
Hubball, H. T., Poole, G. (2003). A learning-centered faculty certificate programme on university teaching. International Journal for Academic Development, 8(1/2), 11-24. doi: 10.1080/1360144042000277900

ICED (2006). The International Consortium for Educational Development in Higher Education. International Journal for Academic Development, 11(1), 67-69. doi:10.1080/13601440600787869

Kabakçı, I., Odabaşı, H. F. (2008). The organization of the faculty development programs for research assistants: The Case of Education Faculties in Turkey. The Turkish Online Journal of Educational Techno$\log y$ (TOJET), 7(3).

Kizıltepe, Z. (2010). Purposes and identities of higher education institutions, and relatedly the role of the faculty. Eurasian Journal of Education and Research, (40), 17-31.

Kiraz, E., Özdemir, D. (2006). The relationship between educational ideologies and technology acceptance in preservice teachers. Educational Techno$\log y$ \& Society, 9(2), 152-165.

Kisner, M. J., Elliott, F. E., Foster, P. M., Covington, M. A., King, M. G. \& Liou, K. T. (1998). Professional development needs assessment survey of inservice clients of the center for vocational professional personnel development at the Pennsylvania State University. Pittsburg: Pennsylvania State University, The Center for Vocational Professional Personnel Development.

Knowles, M. (1984). The Adult Learner: A Neglected Species. Houston: Gulf. ISBN:0-87201-005-8

Kolb, D. A. (1984). Experiential Learning experience as a source of learning and development. New Jersey: Prentice Hall. ISBN: 9780132952613

Lally, V. \& McConnell, D. (2005). Networked professional development. Fallows \& R. Bhanot (Ed.), The staff and educational development series, Quality issues in ICT-based higher education. NY: RoutledgeFalmer. ISBN:0-415-33520-5 
Layne, J., Froyd, J, Simpson, N., Caso, R. \& Merton, P. (2004). Understanding and improving faculty professional development in teaching. ASEE/IEEE Frontiers in Education Conference'da sunuldu. Erişim http:// fie-conference.org/fie2004/papers/1420.pdf

Lawler, P. A. \& King, K. P. (2000). Planning for effective faculty development: Using adult learning strategies. Professional Practices in adult education and human resource development. FL: Krieger. ISBN: 1-57524-105-6

McQuiggan, C. A. (2007). The Role of Faculty Development in Online Teaching's Potential to Question Teaching Beliefs and Assumptions. Online Journal of Distance Learning Administration, 10(3).

Moeini, H. (2003). A Need Analysis Study for Faculty Development Programs in METU and Structural Equations Modeling of Faculty Needs. Yayımlanmamış doktora tezi, Middle East Technical University, Ankara. Erişim http://etd.lib.metu.edu.tr/upload/445320/index.pdf

Odabaşı, H. F. (2003). Faculty point of view on faculty development. Hacettepe Üniversitesi Eğitim Fakültesi Dergisi, (24), 86-89.

Odabaşı, H. F. (2005) The status and need for faculty development in Turkey. International Journal of Academic Development, 10(2), 139-142.

ÖSYS (2016). 2016 ÖSYS yerleştirme sonuçlarına ilişkin sayısal bilgiler. Erişim http://dokuman.osym. gov.tr/pdfdokuman/2016/LYS/YerlestirmeSayisalBilgiler10082016.pdf

Randall, L. E. (2008). Rethinking faculty development: Toward sustaining a community of learners. Senate Forum, 24(1),18-22.

Richlin, L. \& Essington, A. (2004). Overview of Faculty Learning Communities. M. D. Cox ve L. Richlin (Ed.), Building faculty learning communities (s. 5-23). New Directions for Teaching and Learning, No. 97, San Francisco: Jossey-Bass. ISBN: 978-0-7879-7568-5
Rhoades, G. (2012). Faculty Engagement to Enhance Student Attainment. Paper prepared for National Commission on Higher Education Attainment. Erişim https://www.acenet.edu/news-room/Documents/Faculty-Engagement-to-Enhance-StudentAttainment--Rhoades.pdf

Saena, A. (2003). Arizona State University East Professional Development Survey Report. Erişim http:// poly.asu.edu/Final\%20Survey\%20Report[1].pdf

Salmon, G., Angood, R. (2013). Sleeping with the enemy. British Journal of Educational Technology. 44(6), 916-925. doi: 10.1111/bjet.12097

Shephard, K. (2004). The role of educational developers in the expansion of educational technology. International Journal for Academic Development, 9(1), 67-83. doi: 10.1080/1360144042000296062

Sherer, P.D., Shea, T. P. \& Kristensen, E. (2003). Online communities of practice: A catalyst for faculty development. Innovative Higher Education, 27(3), 183-194. doi:10.1023/A:1022355226924

Soran, H., Akkoyunlu, B. \& Kavak, Y. (2006). Life-long learning skills and training faculty members: A project at Hacettepe University. Hacettepe University Journal of Education, 30, 201-210.

Sorcinelli, M. D., Austin, A. E., Eddy, P. L. \& Beach, A.L. (2006). The evolution of faculty development. Creating the Future of Faculty Development: Learning From the Past, Understanding the Present. MA: Anker. ISBN: 978-1-882982-87-5

Sydow, D. L. (1993). A plan for revitalization: Maximizing professional development Opportunity. Report prepared for the Virginia Community College System in April, 1993.

Sydow, D. L. (1998). Outcomes of the VCCS Professional Development Initiative: 1993-1998. Report prepared for the Virginia Community College System (VCCS) in February, 1998. 
Taylor, A. \& McQuiggan, C. (2008). Faculty development programming: If we build it, will they come? Educause Quarterly, No. 3.

Ünver, G. (2010). Faculty members' efficiency in learner-centered approach: Perspectives. Eurasian Journal of Education and Research, (41).

Vaughan, N. (2004). Technology in support of Faculty Learning Communities. M. D. Cox ve L. Richlin (Ed.), Building faculty learning communities (s. 5-23). New Directions for Teaching and Learning: No. 97, San Francisco: Jossey-Bass. ISBN: 978-07879-7568-5

Villar Angulo, L. M. \& Alegre de la Rosa, O. M. (2006). Online faculty development in the Canary Islands: A study of e-mentoring. Higher Education in Europe, 31(1), 65-81. doi:10.1080/03797720600861243
Wallin, D.L. \& Smith, C. L. (2005). Professional development needs of full-time faculty in technical Colleges. Community College Journal of Research and Practice, 29(1), 87-108.

Yılmaz, D. \& Kılıçoğlu, G. (2013). Resistance to change and ways of reducing resistance in educational organizations. European Journal of Research on Education, 1(1), 14-21.

YÖK (2016). Yükseköğrenim Bilgi Yönetim Sistemi. Erişim http://istatistik.yok.gov.tr 